\title{
Controlling of Reactive Power in Transmission Line using Facts Technology with Closed Loop Controller
}

\author{
S.D.Sundarsingh Jebaseelan, D.Godwin Immanuel, M.Kavitha, S.M. Shyni, D.N.S.Ravikumar
}

\begin{abstract}
The paper proposes the power flow control in the transmission line using FACTS devices. In the existing system the power flow in the line system is controlled by using STATCOM. In the proposed system we are going to implement the Combined FACTS device. Which is a combination of series and shunt controller like HPFC (Hybrid power flow controller). Comparison of open loop and closed loop are analyzed for fourteen bus system. In the closed loop PI and FOPID are analyzed for both FACTS Devices. The simulation of both open loop and closed loop are done in the Matlab software.
\end{abstract}

Index Terms: FACTS, STATCOM, HPFC, FOPID

\section{INTRODUCTION}

A lot of energy is being consumed for the consumer needs and household usages and many industrial purposes due to this high usage there is a lot of drop in the voltage and causes fault in the transmission lines and to avoid that condition we are going to introduce the FACTS devices that will control the reactive power and stores the reactive power and helps in emitting that same reactive power whenever there is a drop in the transmission line and as the reactive power is directly proportional to the voltage as the control of the voltage in the transmission line will be difficult so by controlling the reactive power we can control the voltage this is the main principle behind the usage of FACTS devices. They are different types of the FACTS devices static shunt compensator SVC, TCR, TSC, STATCOM and combined compensators IPFC, UPFC, HPFC. STATCOM [8] is a device which can supply the required reactive power at low values of bus voltage and can also supply active power if it has large energy storage. STATCOM is a shunt connected reactive power compensation device it is capable of generating and absorbing the reactive power. [2-3]

HPFC is combined compensators where the device is the combination of both series and shunt compensators. HPFC is used to deal with the above problems namely high cost

Revised Manuscript Received on October 30, 2019

* Correspondence Author

Dr.S.D.Sundarsingh Jebaseelan*, EEE, Sathyabhama, Chennai, India. Dr,D,Godwin Immanuel, EEE, Sathyabhama, Chennai, India.

M.Kavitha, EEE, Sathyabhama, Chennai, India

S.M/Shyni, EEE, Sathyabhama, Chennai, India

D.N.S.Ravikumar, EEE, Sathyabhama, Chennai, India

(C) The Authors. Published by Blue Eyes Intelligence Engineering and Sciences Publication (BEIESP). This is an open access article under the CC BY-NC-ND license (http://creativecommons.org/licenses/by-nc-nd/4.0/) efficiency and also if focuses on grid connection and operating performance. [1]

\section{METHODOLOGY}

\section{A. Existing Method}

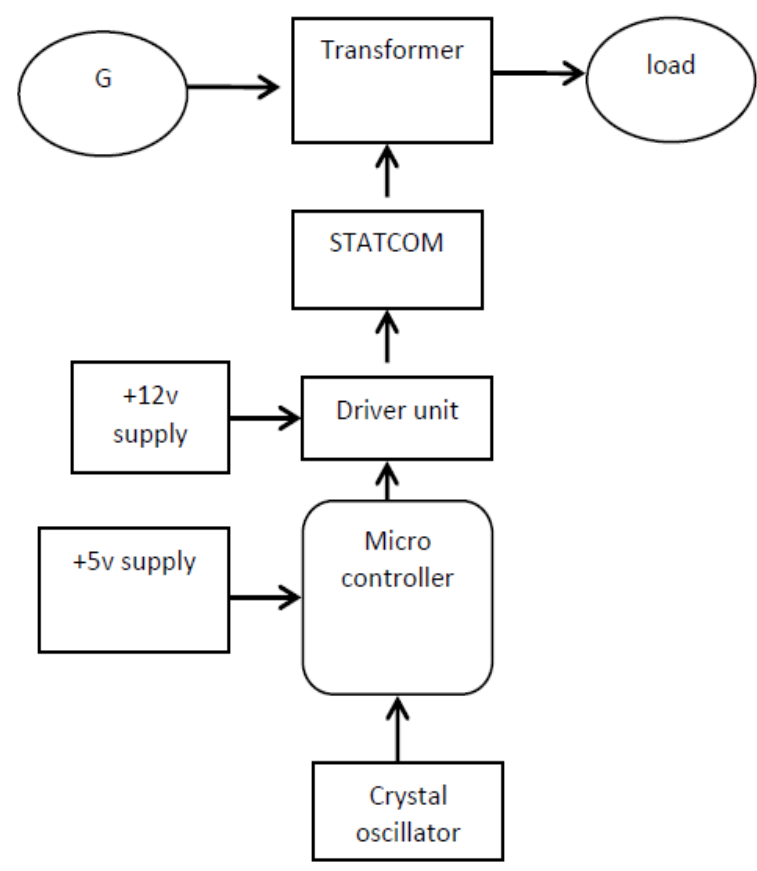

Fig 1: Existing method of block diagram

The above block diagram shows the Generator supply is given to the transformer and the Crystal oscillator to the Micro Controller which consists a supply of $+5 \mathrm{v}$ and the micro controller is connected to Driver Unit the driver unit consists of a supply of $+12 \mathrm{v}$ and thus the driver unit is connected to the STATCOM and STATCOM is been connected to the Transformer to the Load. [4,5] 


\section{A. Proposed Method}

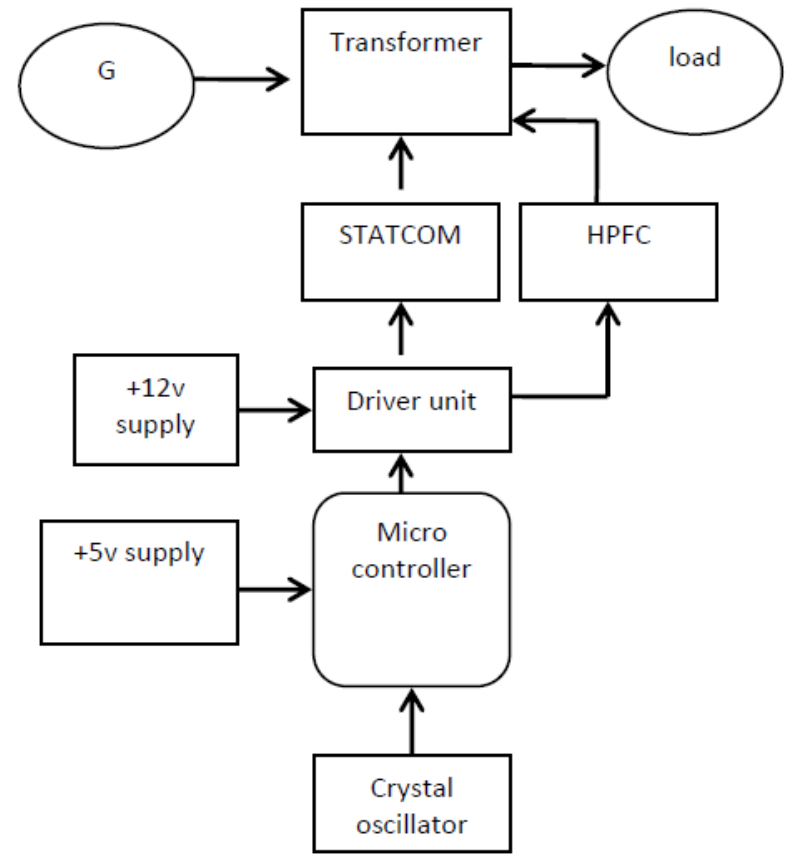

Fig 2: Proposed method of block diagram

The above block diagram shows the Generator supply is given to the Transformer and the Crystal Oscillator is to the Micro Controller which consists of a supply of $+5 \mathrm{v}$ and the micro controller is connected to the Driver Unit and thus a supply of $+12 \mathrm{v}$ is given to the driver unit and the driver unit is connected to the STATCOM and HPFC $[3,6]$ and thus from the HPFC to the Transformer also from STATCOM to the Transformer and thus both is being connected to the Load.

\section{SIMULATION RESULTS}

A. 14 bus system with open loop

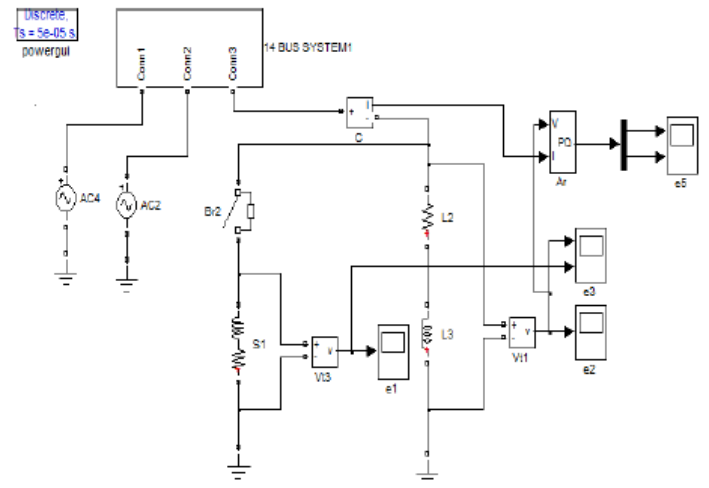

Fig 3: Simulation Circuit Diagram of 14 Bus System

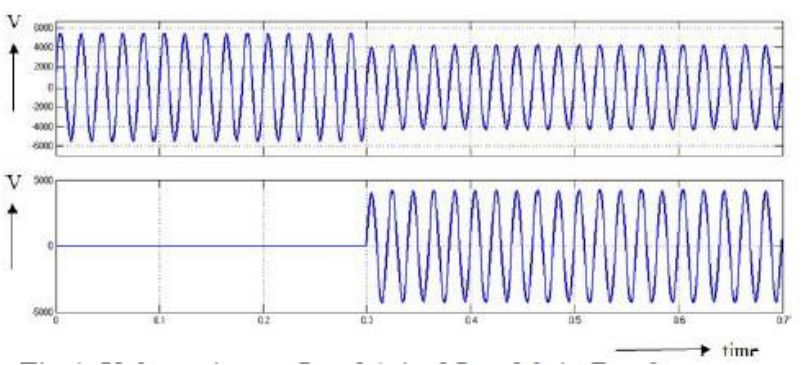

Fig 4: Voltage Across Load 1 And Load 2 At Bus 3
The above graph explains about the voltage across the loads one and two across the bus -3 in 14 bus system without any FACTS devices as the $\mathrm{x}$ axis is time and $\mathrm{y}$ axis is voltage.

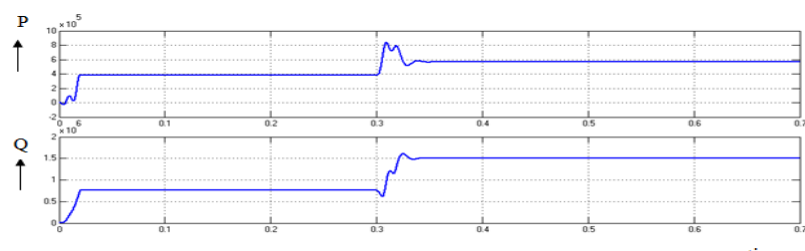

Fig 5: Real and Reactive Power At $\overline{B u s} 3$

The above graph explains about the real and reactive power across the bus 3 in 14 bus system without any FACTS devices.

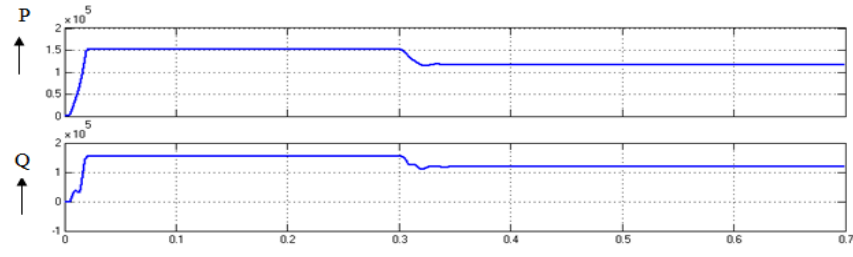

Fig 6: Real and Reactive Power at Bus 6

The graph mentioned above explains about the real and reactive power across the bus 6 in 14 bus system after compensation without any FACTS devices.

B. 14 bus system with STATCOM open loop

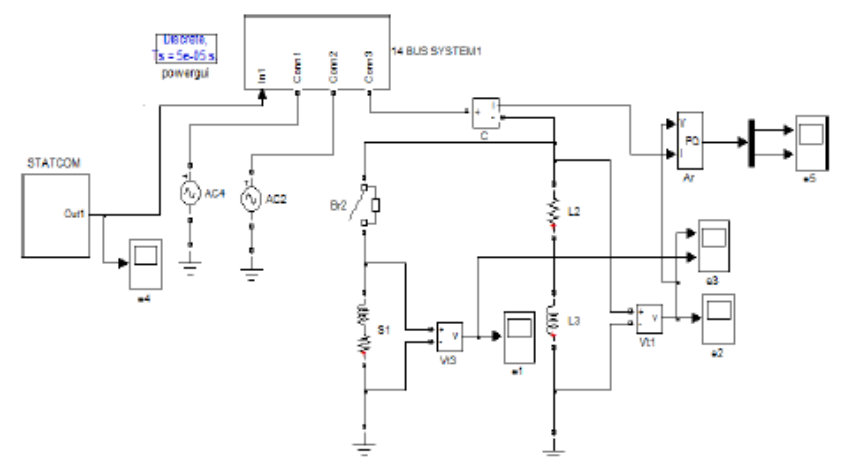

Fig 7: Simulation circuit of 14 bus line system using STATCOM with open loop

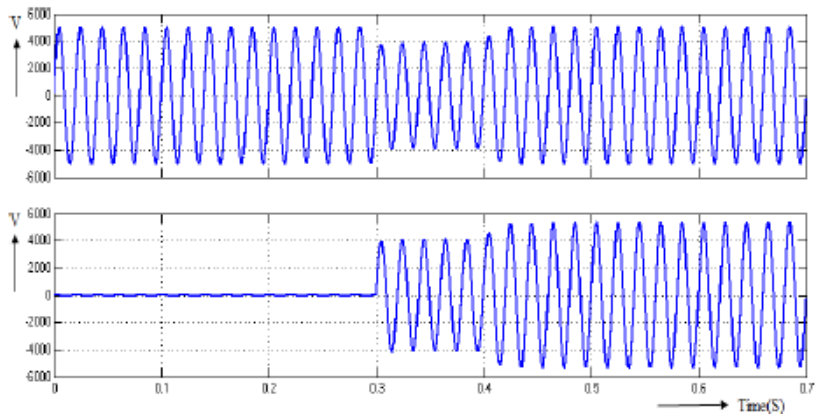

Fig 8: Voltage across Load -1 and load-2 at bus-3

The above graph explains about the voltage across the load 1 and load 2 at bus 3 in 14 bus system using STATCOM. 


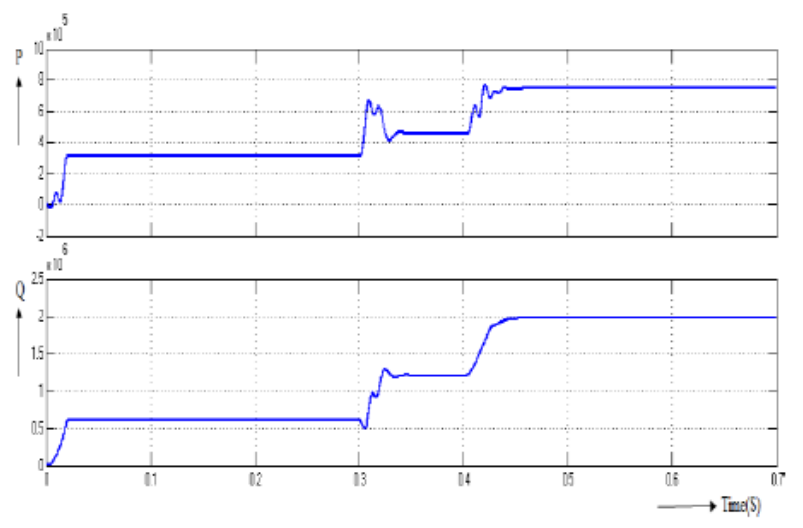

Fig 9: Real and Reactive power at bus-3

The above graph explains about the real and reactive power across the bus 3 in the 14-bus line system with the FACTS device with STATCOM as there is a drop in the voltage then the real and reactive power will increase in the transmission line.

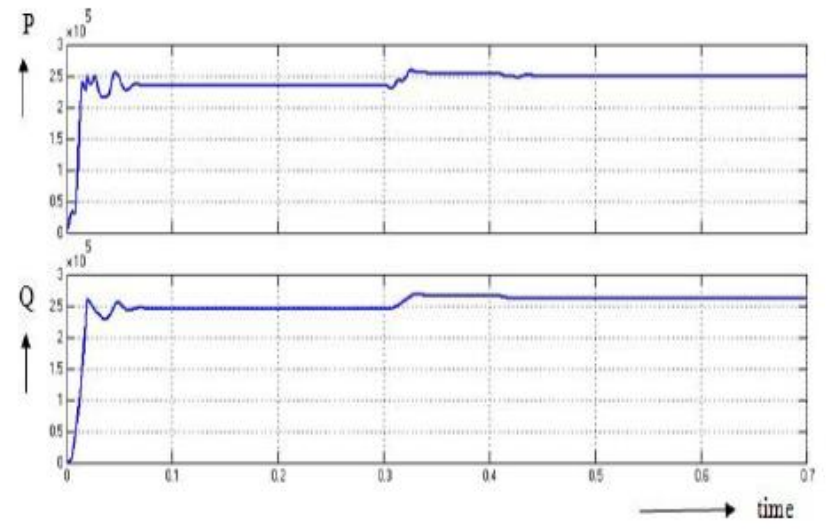

Fig 10: Real and Reactive power at bus-6

The above graph explains about the real and reactive power across the bus 6 using STATCOM in the 14-line bus system after compensation.

C. 14 bus system using combined FACTS Device with open loop

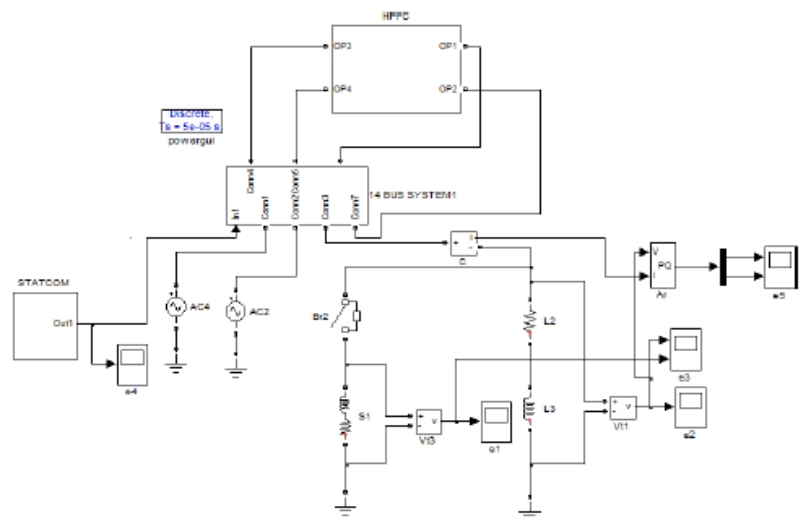

Fig 11: simulation circuit diagram using STATCOM and HPFC

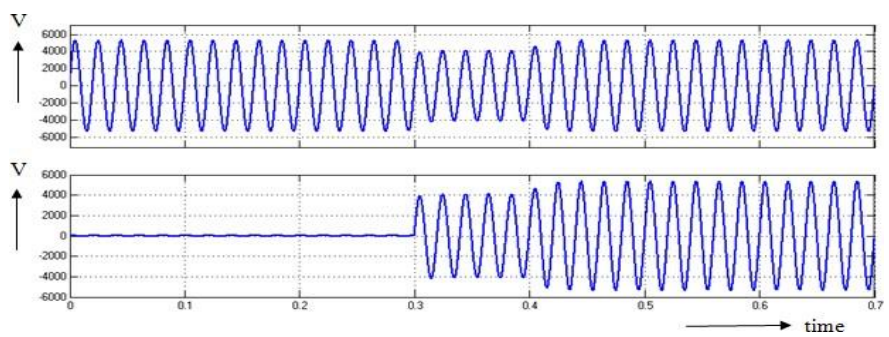

Fig 12: Voltage across Load -1 and load-2 at bus-3

The above graph explains about the voltage across the load 1 and load 2 at the bus 3 with the combined FACTS devices called STATCOM and HPFC in the 14-line bus system.

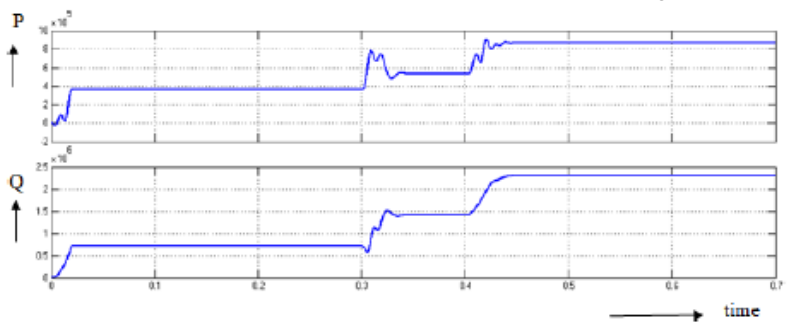

Fig 13: Real and Reactive power at bus-3

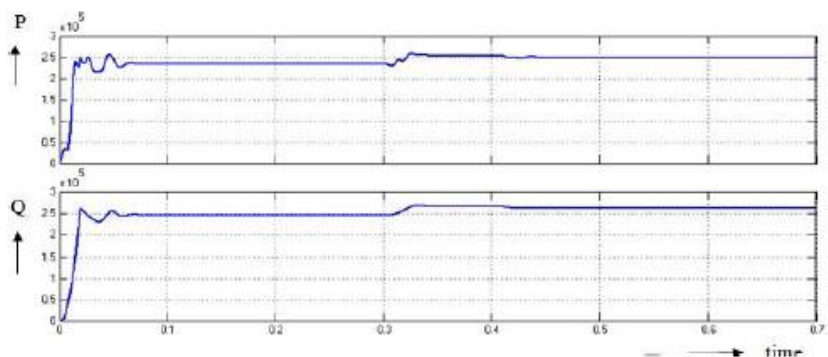

Fig 14 Real and Reactive power at bus-6 D. PI Controller with Combined FACTS

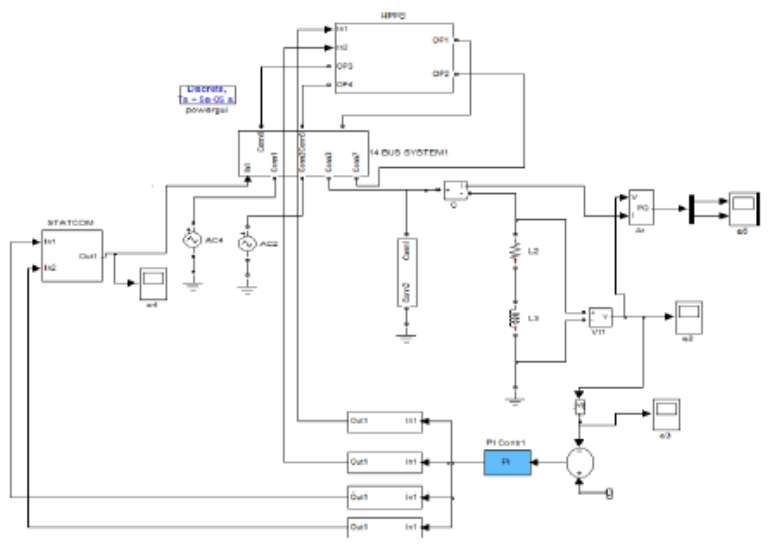

Fig 15: simulation circuit diagram in closed loop using PI controller

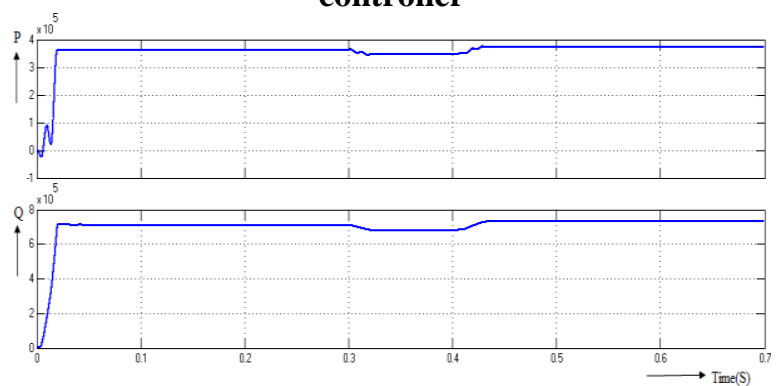

Fig 16 Real and reactive power at bus3 using PI controller

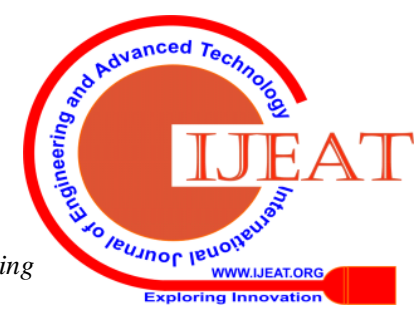




\section{Controlling of Reactive Power in Transmission Line using Facts Technology with Closed Loop Controller}

The above graph explains about the real and reactive power across the bus 3 in the 14-bus line system by closed loop using PI controller using combined FACTS devices STATCOM and HPFC.

\section{E. FOPID Controller with Combined FACTS}

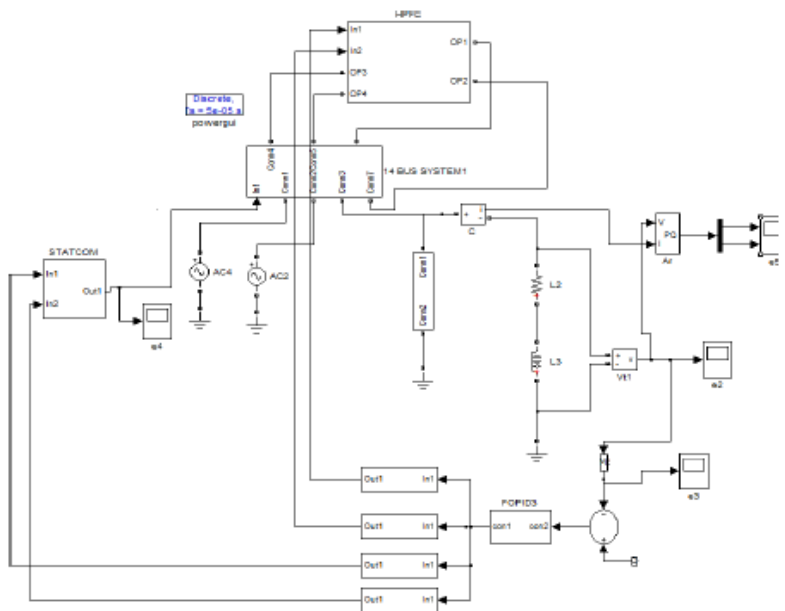

Fig 17: simulation circuit diagram in closed loop using FOPID controller

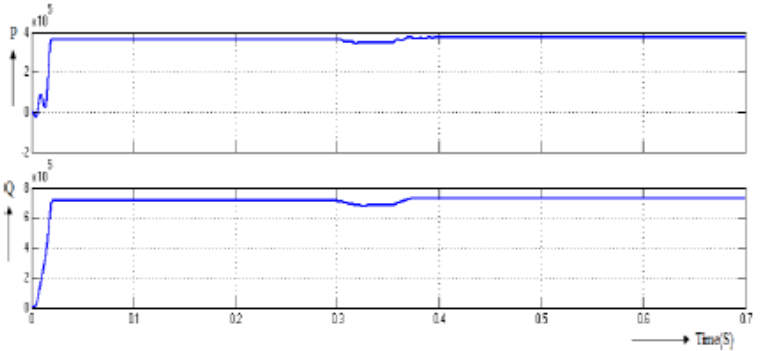

Fig 18 Real and reactive power at bus3 using FOPID controller

The above graph explains about the real and reactive power across the bus 3 in the 14-bus line system in the closed loop using FOPID controller with the help of combined FACTS devices STATCOM and HPFC.

Table 1: Comparison of Real Power at Bus 3 and 6

\begin{tabular}{|c|l|l|l|l|l|}
\hline $\begin{array}{l}\text { Bus } \\
\text { No }\end{array}$ & \multicolumn{5}{|c|}{ Real power } \\
\cline { 2 - 6 } & $\begin{array}{l}\text { Without } \\
\text { FACTS } \\
\text { devices }\end{array}$ & $\begin{array}{l}\text { With } \\
\text { STATCOM } \\
\text { (open loop) }\end{array}$ & $\begin{array}{l}\text { With } \\
\text { STATCOM } \\
\text { (Closed } \\
\text { loop) }\end{array}$ & $\begin{array}{l}\text { With } \\
\text { combined } \\
\text { STATCOM } \\
\text { \& HPFC } \\
\text { (open loop) }\end{array}$ & $\begin{array}{l}\text { With } \\
\text { combined } \\
\text { STATCOM } \\
\text { \& HPFC } \\
\text { (closed loop) }\end{array}$ \\
\hline 3 & 0.0603 & 0.0755 & 0.0798 & 0.0825 & 0.0963 \\
\hline 6 & 0.0155 & 0.0223 & 0.0294 & 0.0354 & 0.0396 \\
\hline
\end{tabular}

Table 2: Comparison of Reactive Power at Bus 3 and 6

\begin{tabular}{|c|l|l|l|l|l|}
\hline \multicolumn{3}{|c|}{$\begin{array}{l}\text { Bus } \\
\text { No }\end{array}$} & \multicolumn{5}{|c|}{ Reactive power } \\
\cline { 2 - 6 } & $\begin{array}{l}\text { Without } \\
\text { FACTS } \\
\text { devices }\end{array}$ & $\begin{array}{l}\text { With } \\
\text { STATCOM } \\
\text { (open loop) }\end{array}$ & $\begin{array}{l}\text { With } \\
\text { STATCOM }\end{array}$ & $\begin{array}{l}\text { With } \\
\text { combined } \\
\text { STATCOM } \\
\text { \& HPFC } \\
\text { (Closed } \\
\text { loop) }\end{array}$ & $\begin{array}{l}\text { With } \\
\text { combined } \\
\text { STATCOM } \\
\text { \& HPFC } \\
\text { (closed loop) }\end{array}$ \\
\hline 3 & 0.0156 & 0.1981 & 0.2014 & 0.2363 & 0.2409 \\
\hline 6 & 0.0164 & 0.1223 & 0.2297 & 0.2352 & 0.3108 \\
\hline
\end{tabular}

Table 3: Comparison of Time Domain Parameters

\begin{tabular}{|c|c|c|c|c|}
\hline Controllers & Tr & Ts & Tp & Ess \\
\hline PI & 0.33 & 0.42 & 0.37 & 3.8 \\
\hline FOPID & 0.32 & 0.36 & 0.34 & 2.2 \\
\hline
\end{tabular}

6 with PI \& FOPID Controller

\begin{tabular}{|c|c|c|c|c|}
\hline & \multicolumn{2}{|c|}{ Real Power } & \multicolumn{2}{|c|}{ Reactive Power } \\
\hline $\begin{array}{l}\text { Bus } \\
\text { No }\end{array}$ & \begin{tabular}{l|} 
With \\
STATCOM \\
(PI \\
Controlle \\
r)
\end{tabular} & $\begin{array}{l}\text { With } \\
\text { combined } \\
\text { STATCOM } \\
\text { \& HPFC } \\
\text { (FOPID } \\
\text { Controller) } \\
\end{array}$ & $\begin{array}{l}\text { With } \\
\text { STATCOM } \\
\text { (PI } \\
\text { Controller) }\end{array}$ & $\begin{array}{l}\text { With combined } \\
\text { STATCOM \& } \\
\text { HPFC } \\
\text { (FOPID } \\
\text { Controller) }\end{array}$ \\
\hline 3 & 0.0583 & 0.0963 & 0.165 & 0.2409 \\
\hline 6 & 0.01257 & 0.0396 & 0.251 & 0.3108 \\
\hline
\end{tabular}

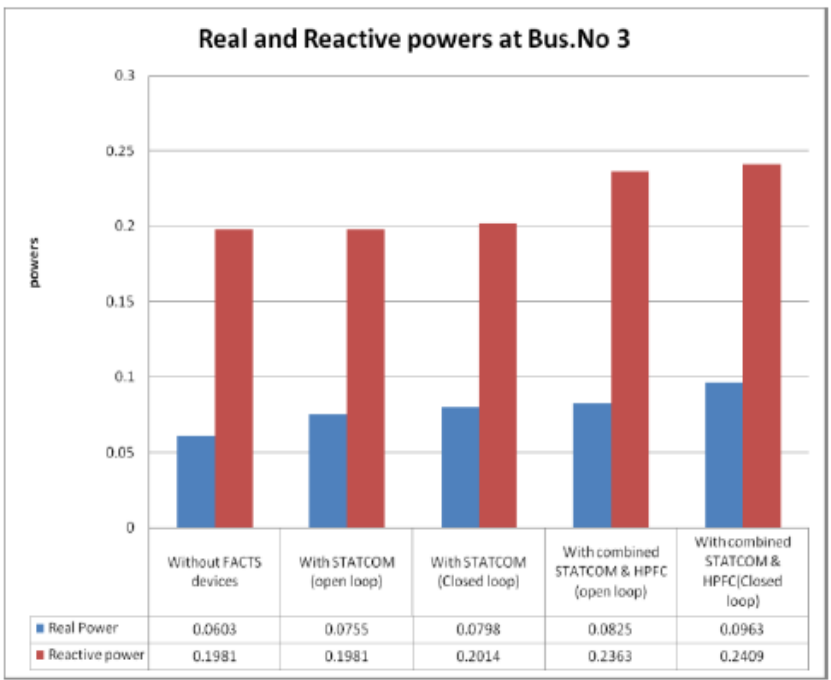

Fig 19: Graph of Real and Reactive Power at Bus 3

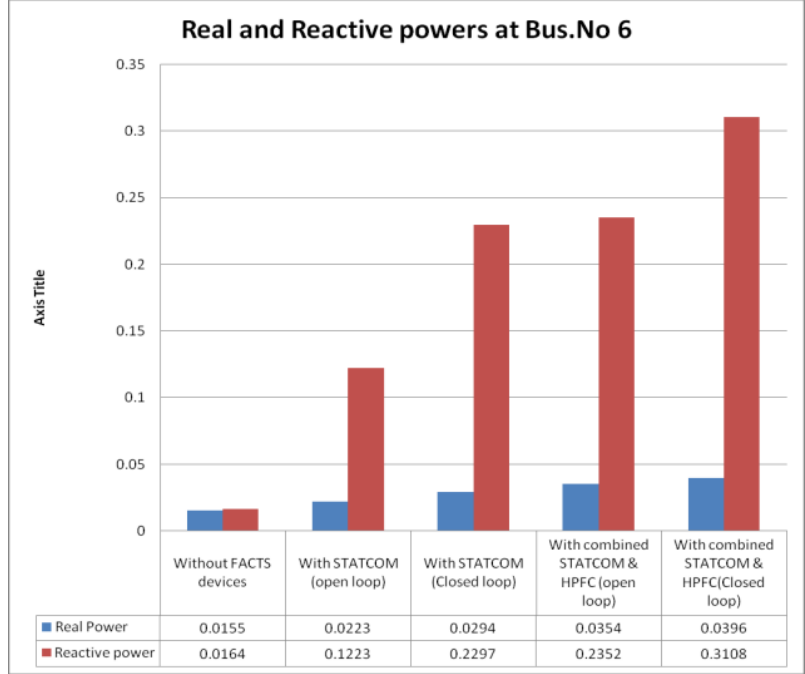

Fig 20: Graph of Real and Reactive Power at Bus 6 


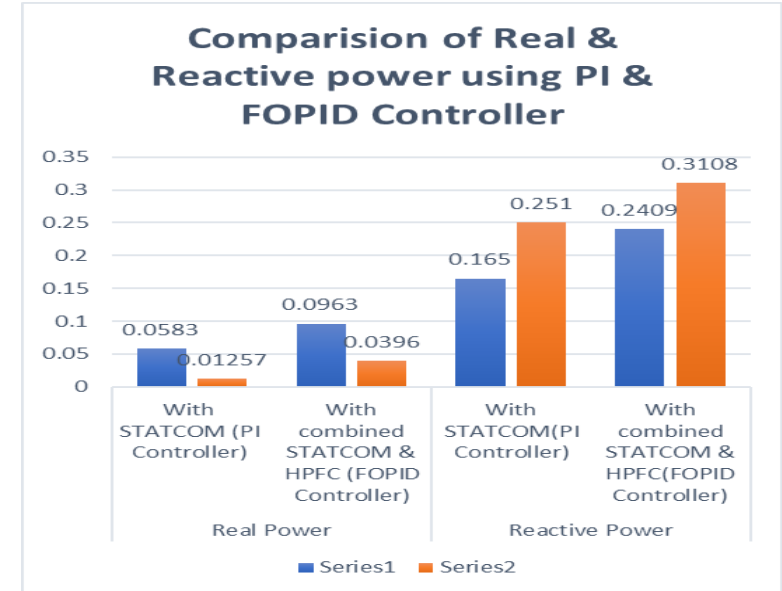

Fig 21: Graph of Real \& Reactive power using PI \& FOPID Controller

\section{RESULTS AND DISCUSSION}

The performance of the proposed scheme is higher when compared to the present system the real power across the bus 3 is 0.063 and at bus 6 is 0.0155 without using any FACTS devices.

By using the STATCOM open loop across bus 3 and bus 6 real power increase of value to 0.075 and at bus 6 to 0.0223 . By using the STATCOM and HPFC in open loop across bus 3 and bus 6 real power increase of value to 0.0825 at bus 3 and bus 6 to 0.0354 .

By using the STATCOM in PI Controller in bus 3 and bus 6 real power increase of value to 0.0798 at bus 3 and bus 6 to 0.0294

By using the STATCOM and HPFC in FOPID controller across bus 3 and bus 6 there is an increase of value to 0.0963 at bus 3 and 0.0396 at bus 6 . From we can find that real power has been compensated by $73 \%$.

The reactive power values across the bus 3 and bus 6 without FACTS devices are 0.0156 at bus 3 and 0.0164 at bus 6 . By using the STATCOM across bus 3 and bus 6 there is an increase of value to 0.1981 at bus 3 and 0.1223 at bus 6 . By using the STATCOM and HPFC across bus 3 and bus 6 there is an increase of value to 0.2363 at bus 3 and 0.2352 at bus 6 .

\section{CONCLUSION}

In the proposed work, FOPID controllers have been implemented for combined FACTS devices. After the implementation of FOPID in STATCOM across bus 3 and bus 6 there is an increase of value to 0.2014 at bus 3 and 0.2297 at bus 6. By using the STATCOM and HPFC (FOPID) across bus 3 and bus 6 there is an increase of value to 0.2409 at bus 3 and 0.3108 at bus 6 . Using FOPID Combined FACTS devices reactive power is compensated to $88 \%$.. By using this controller, the reactive power is improved so the stability of the system is maintained.

\section{REFERENCES}

1. Abinaya.I, S.D.Sundarsingh Jebaseelan and C.N.Ravi,“ Reactive Power Compenstion in Grid System using STATCOM with Closed loop Control,' Indian Journal of Science and Technology, Vol 9(6), pp 1- 4 , February 2016.

2. Marlin.S, S.D.Sundarsingh Jebaseelan, B. Padmanabhan and G.Nagarajan, "Power Quality Improvement for Thirty Bus system using UPFC and TCSC," Indian Journal of Science and Technology, Vol 7 (9), pp 1316 - 1320, September 2014.
3. S.Marlin, S.D.SundarsinghJebaeelan and C.N.Ravi, "Closed loop control for reactive power compensation using combined facts devices", ARPN Journal of Engineering and Applied Sciences, ISSN 1819-6608. Volume 10, Issue Number 21 (2015). pp - 9953 - 9957.

4. S.D.Sundarsingh Jebaseelan and D.Godwin Immanuel, "Reactive power compensation using STATCOM with PID controller", International Journal of Applied Engineering, ISSN 0973-4562 Volume 9, Number 21 (2014), pp 11281 - 11290.

5. Raja G. and S. D. Sundarsingh Jebaseelan., "Multilevel Inverter Based Power Quality Improvement For STATCOM", ARPN Journal of Engineering and Applied Sciences, ISSN 1819-6608. Volume 11, Issue

Number 9, May 2016, pp - 5826 - 5829.

6. S.D.Sundarsingh Jebaseelan, C.N.Ravi, G.Nagarajan and S.Marlin, "Closed loop control of FACTS Devices in Power Systems", Springer, Advances in Intelligent Systems and Computing, Volume 1, PP 361 369, 2016.

7. A.Murugan, G.Nagarajan, S.D.SundarsinghJebaseelan and C.N.Ravi, "Performance Analysis of Voltage Profile, Power, Angle of injection using combined FACTS device", International Journal of Applied Engineering, ISSN 0973-4562 Volume 9, Number 21 (2014), pp 10303 -10316 .

8. S.D.Sundarsingh Jebaseelan and Dr. R. Raja Prabu, "Modelling and Simulation of Thirty Bus System Using Multiple STATCOM \& TCTC", European Journal of scientific Research, ISSN 1450-216X Vol.81 No.2 (2012), pp.285-297, July 2012.

9. R.R.Selva Yogesh and S.D.SundarsinghJebaseelan, "Design and Implementation of Energy Conservation hybrid System with Fuzzy Control for DC Micro Grid System”, International Journal of Applied Engineering, ISSN 0973-4562, Volume 10, Number 6 (2015), pp 5698 -5704 .

10. Godwin Immanuel .D, Dayana D S and Sundarsingh Jebaseelan S D, "Hybrid Genetic Algorithm Assisted Artificial Bee Colony Approach for Voltage Stability Improvement", International Journal of Applied Engineering, ISSN 0973-4562, Volume 10, Number 59 (2015), pp 534 $-541$

11. D. Godwin Immanuel, G. Selvakumar, and ,C. Christober Asir Rajan, "A Multi Objective Hybrid Differential Evolution Algorithm assisted Genetic Algorithm Approach for Optimal Reactive Power and Voltage Control", International Journal of Engineering and Technology,Vol.6, Issue-1, 2014,pp.199-203

\section{Authors Profile}

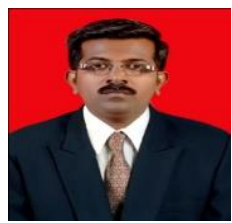

Dr.S.D.Sundarsingh Jebaseelan received his Bachelor of Engineering degree in Electrical and Electronics Engineering in the year 2002 from the Bharthiyar University, Coimbatore, Tamilnadu and Master of Engineering degree in Power Systems in the year 2005 from Annamalai University, Chidambaram, Tamilnadu and also he received his Doctor of Philosophy in the year 2014 from Sathyabama University, Chennai $\mathrm{He}$ is currently working as an Associate Professor in the Department of Electrical and Electronics Engineering, Sathyabama Institute of Science and Technology, Chennai. He has published four Book Series, Twelve International Journal papers, Ten National Journal and Ten papers in National Conferences and Six papers in International Conferences. He is Life Member of International Association of computer science and Information Technology

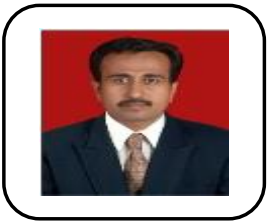

D. Godwin Immanuel was born in Nagercoil, Tamilnadu. He completed his B.E degree in Electrical and Electronics Engineering in Manonmaniam sundarnar university, Tirunelveli. He later completed his Masters in Power system Engineering in Annamalai University and completed his Phd in Sathyabama University. He has published more than 40 papers in various Journals and Conferences. His research interest includes Power Sytem Optimization problems.

Published By: 


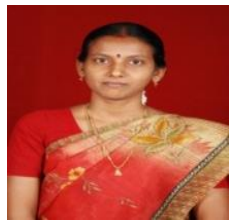

M.Kavitha has received her B.E degree in Electrical and Electronics Engineering from Bharathiyar University, Tamilnadu, India in 2000 and M.E degree in Power Systems Engineering from Anna University, Tamilnadu, India in 2012. She is pursuing her Ph.D under the faculty of Electrical and Electronics Engineering at Sathyabama Institute of Science and Technology from 2014. Her research interest includes Renewable Energy sources, Energy storage system, Fuzzy logic controller, Artificial Neural network and Power Electronic Converters.

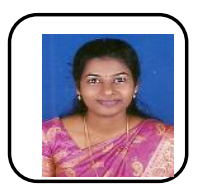

S.M.Shyni, received her M.E Applied Electronics in the year 2012. Currently, she is working as an Assistant Professor in the Department of Electrical and Electronics Engineering, Sathyabama Institute of Science and Technology, Chennai. She has more than 8 years of experience in teaching field. She is undergoing her research in Utilization of Renewable energy in the department of Electronics Engineering, Sathyabama Institute of Science and Technology, Chennai. Her current research area focuses on Soft Computing Techniques.

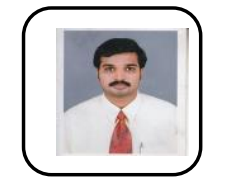

D.N.S Ravi Kumar has completed his M.Sc.(Applied Electronics ) in the year 2003 from Bharathiyar University Coimbatore ,India and M.E Applied Electronics in the year 2006 from Sathyabama Institute of Science \& Technology Chennai India.He is pursing $\mathrm{PhD}$ in the field of Vehicular Communication (Distributed Embedded Systems) from Sathyabama Institute of Science and Technology since 2015,Chennai India.His field of intrests includes Embedded Systems ,Vehicular Communication and Robotics. He is currently working on Smart car Technology (V2V).Apart from research an innovator to spark startups from ideas to implementation. 